\title{
DISCRIMINANT ANALYSIS THROUGH FISHER METHOD ON STUDENT'S MATERIALS BUILDING IN SMP 1 BANDA ACEH
}

\author{
Yuhasriati $^{1}$, Johan Yunus ${ }^{2}$, Erni Maidiyah ${ }^{3}$, Bintang Zaura ${ }^{4}$ \\ Department of Mathematic Education, Syiah Kuala University
}

E-mail: yuhasriati@unsyiah.ac.id

Diterima: 09/08/2019; Disetujui: 29/08/2019

\begin{abstract}
ABSTRAK
The study is done for determining how many students and how the percentage of students who have mastered the material geometry about prism and pyramid, and getting the discriminant function about the mastery of the material. The study population was the entire eighth grade students of SMP Kasih Banda Aceh while the sample were students of class VIII-1 and VIII-8 to 66 students. Based on the research that has been done using the fisher discriminant analysis method, $18,18 \%$ of students have mastered the material geometry and $81,82 \%$ of students have not mastered the material geometry. It means that from 66 students only 12 students were able to master the material geometry about well- prism and pyramid. The discriminant function that is formed is $Y_{1}=955,086 X_{1}+1583,05 X_{2}-28,202 X_{3}-$ $127,773 \mathrm{X}_{4}-120,111 \mathrm{X}_{5}-92,511 \mathrm{X}_{6}$ and $\mathrm{Y}_{2}=956,411 \mathrm{X}_{1}+1589,179 \mathrm{X}_{2}-$ $34,065 X_{3}-137,536 X_{4}-120,797 X_{5}-82,946 X_{6}$.
\end{abstract}

Kata Kunci: Discriminant Analysis, Fisher, Geometry, Prism, And Pyramid 


\section{BACKGROUND}

Mathematics has an important role in everyday life. Therefore, this math needs to be taught from every level of education from elementary to university. According to Ockroft in (Abdurrahman, 2003: 258) suggests that mathematics should be taught to students because 1) Always used in all aspects of life, 2) All fields of study require appropriate mathematical skills, 3) Is a powerful, clear, 4) Can be used to present information in various ways, 5) Improve the ability of logical thinking, thoroughness, and spatial awareness, 6) Give satisfaction to the business of solving challenging problems.

According to Slameto (2010: 2), learning is a process of business undertaken by a person to gain a new change of behavior as a whole, as a result of his own experience in interaction with his environment. Learning is a process marked by a change in a person. Change as a result of various forms such as changes in knowledge, understanding of attitudes, behavior, skills, abilities, habits and other aspects of change that exist in the learning individual. The process of learning is very difficult to observe. Therefore, people tend to see human behavior to be organized into patterns of behavior that eventually composed a model that became the principles of learning that are useful as a provision to understand, encourage, and give direction learning activities.

According to Slameto $(2010: 27)$ that the principles of learning that can be implemented in different situations and conditions and by each learner individually is 1) Based on the necessary prerequisites for learning. In learning learners cultivated active participation, increased interest, and guided to achieve the instructional objectives. 2) According to the nature of learning. Learning is the process of contingency (the relationship of other understandings) so it gets the expected understanding of the given stimulus can cause the expected response. 3) Appropriate material or materials to be studied.learning is overall and the material must have a presentation structure that can be caught understanding.4) Terms of learning success.
Learning requires adequate facilities so that learners can learn quietly.

According to the development team of MKDK IKIP Semarang in Sacramento (2003: 20-25), student learning is influenced by two factors, namely internal factors and external factors. Internal factors are factors that exist within the individual, while external factors are factors that exist outside the individual self. Internal factors include 1) physical factors, ie factors related to one's condition, 2) psychological factors, there are several factors included in the factor psychology, among others: intelligence, attention, interest, talent, motive, maturity, and also fatigue, 3) fatigue factor, physical fatigue seen from weak body, spiritual fatigue can be seen from the lethargy and boredom. External factors include 1) family factors, including economic circumstances, parenting ways of education, relationships among family members, parental understanding, home atmosphere, and cultural background, 2) school factors, affecting learning including teacher teaching methods, curriculum, relationships between teachers and students, the relationship between students and students, and learning tools, 3) environmental factors, which affect learning are classified into two groups, namely social environmental factors and nonsocial environmental factors.

A school institution has a responsibility to carry out the objectives of the learning process, specially for geometry materials. Geometry is an important component of the mathematics curriculum in junior high school. One of the topics discussed in geometry is waking up space. Some sub-spaces in the wake of space are prisms and pyramid.

In the implementation not far from the mistakes that occur so that the achievement of the implementation of learning objectives inhibited such as mistakes in understanding the concept of a material. To prevent errors that occur in the learning process can be done by grouping students who are able to master the learning materials with the less able to understand the subject matter so that for students who have not been able to master the material can be added to 
the lesson. Teachers can group the students using discriminant analysis.

Discriminant analysis is one of the statistical techniques that can be used in the dependency relationship (the relationship between variables where it can be distinguished where the response variable and where the explanatory variable). Discriminant analysis can be done manually and SPSS software assistance (version 16.0). By using the software will be easier for us in determining the discriminant of these variables.

This analysis is based on a discriminant function that has a common form:

$$
Y_{i}=\beta_{0}+\beta_{1} X_{1}+\beta_{2} X_{2}+\cdots+\beta_{p} X_{p}+\varepsilon_{l}
$$

Johnson and Wichern in Wahyuni (2011: 10) explains that Fisher discriminant analysis is one method of obtaining the discriminant function. Fisher's linear method actually comes from linear classification statistics for two normal populations. In this method $\mathrm{X}$, multivariate observations are transformed to univariate observations of $\mathrm{Y}$ where $\mathrm{Y}$ comes from the first and second populations to be separated as much as possible for other observations. Fisher's suggests taking a linear combination of $\mathrm{X}$ to produce $\mathrm{Y}$ which is a fairly simple function for installation of X.

The formulation of the underlying problem of this research is how many students and what percentage of mastery of the waking material about the prism and pyramid that have been achieved by students, and how the grouping of students who master and who have not mastered the material through discriminant analysis with SPSS software (version 16.0) in SMP Kasih Banda Aceh. The author will discuss discriminant analysis through fisher method to the students' ability in mastering the class VIII SMP Kasih Banda Aceh class building materials. This research was conducted to get discriminant function about the mastery of wake up space about prism and pyramid at SMP Kasih Banda Aceh students.

\section{RESEARCH METHODOLOGY}

The approach used in this research is qualitatively supported by quantitative, while the type of research used is descriptive. As for how to obtain data in this study based on the purpose of this study, the subject of research focused on VIII-1 and VIII-8, because basically all classes consist of heterogeneous students, the researchers chose the class randomly. The way to get data in this research is by using the instrument in the form of pretest, final test (post-test), and semester evaluation value (report card) math and science lesson.

Grouping by discriminant analysis occurs because there is the influence of one or more other variables that are independent variables. The linear combination of these variables will form a discriminant function (Tatham et al., 1998). Discriminant analysis is an accurate technique for predicting a person falling into what category, with the records involved ensuring accuracy. Prior to data processing in discriminant analysis, it is necessary to test the three Fisher's assumptions. This is done to obtain discriminant function as an indicator that gives minimum placement error opportunity. Before the data are analyzed by discriminant, the data are tested the normality by using Q-Q Plots in SPSS (version 16.0). and also testing the similarity (homogeneity) of the matrix.

Testing the equality of the covariance variance matrix of each group to determine the discriminant analysis method to be used. To test the similarity of covariance matrix between variables should be obtained statistic Box's M.

If the data are not normal, changing the data to normal is needed by using function in SPSS. If the data were normal, testing of average vector difference, because the discriminant analysis was done to data that has been valid (valid) its grouping. Discriminant analysis is not useful if the data that has been grouped has a mean value vector that is not significantly different. If the discriminant analysis is still done, then there will be a very big mistake in the grouping. To test the average vector difference can be seen using Wilks' Lambda whose value lies between 0 and 1 .

Each new data (indicator) entered into one of the functions of $\left.\mathrm{Y}_{(\mathrm{x})}\right)$ will be obtained in the form of a value. The value of each function $\mathrm{Y}\left(\mathrm{f}_{(\mathrm{x})}\right)$ is different, the function $\mathrm{Y}\left(\mathrm{f}_{(\mathrm{x})}\right)$ to be selected (categorized) is the function $\mathrm{Y}\left(\mathrm{f}_{(\mathrm{x})}\right)$ which 
yields the highest value. Kathleen and Carmen (2002) argue that each function $\mathrm{Y}\left(\mathrm{f}_{(\mathrm{x})}\right)$ in the SPSS process consists of the variable Xp (indicator) for a classification function for one group. Variables in this Fisher linear discriminant function may be used continuously for the classification or grouping of new data. These variables are obtained for each group and from any new cases inputted and processed, the results are grouped into groups whose discriminant value $\mathrm{Y}\left(\mathrm{f}_{(\mathrm{x})}\right)$ is higher.

\section{RESULTS AND DISCUSSION}

The data collected in this study is derived from initial and final tests of prism and pyramid subjects and for initial test scores and final tests on algebra material obtained from documentation of student learning outcomes in schools as well as the mean values of mathematics and value of science. This is because the value of algebra in this study is only used as a comparison for the value of prism and pyramid. The following table is the data of geometry and algebra materials as well as grades of math and science lesson.

\begin{tabular}{|l|c|c|c|c|c|c|}
\hline \multirow{2}{*}{ Sample } & \multicolumn{2}{|c|}{$\begin{array}{c}\text { The rate of the } \\
\text { Report }\end{array}$} & \multicolumn{2}{c|}{$\begin{array}{c}\text { Prism and } \\
\text { Pyramid }\end{array}$} & \multicolumn{2}{c|}{ Algebra } \\
\cline { 2 - 7 } & Math & Science & Pre & Post & Pre & Post \\
\hline A1 & 84 & 84 & 40 & 60 & 89 & 82 \\
\hline A2 & 88 & 88 & 80 & 85 & 50 & 82 \\
\hline A3 & 96 & 93 & 87 & 90 & 85 & 93 \\
\hline A4 & 96 & 92 & 92 & 90 & 75 & 91 \\
\hline A5 & 94 & 92 & 85 & 87 & 85 & 85 \\
\hline A6 & 96 & 93 & 85 & 90 & 70 & 92 \\
\hline A7 & 96 & 92 & 87 & 90 & 87 & 91 \\
\hline A8 & 91 & 88 & 35 & 60 & 50 & 82 \\
\hline A9 & 83 & 83 & 50 & 60 & 45 & 82 \\
\hline A10 & 95 & 94 & 90 & 95 & 85 & 92 \\
\hline A11 & 82 & 82 & 87 & 90 & 87 & 85 \\
\hline A12 & 96 & 93 & 90 & 95 & 85 & 92 \\
\hline A13 & 92 & 90 & 90 & 90 & 82 & 87 \\
\hline A14 & 92 & 88 & 85 & 90 & 87 & 90 \\
\hline A15 & 92 & 89 & 82 & 85 & 82 & 82 \\
\hline A16 & 87 & 86 & 85 & 85 & 90 & 85 \\
\hline A17 & 86 & 85 & 65 & 80 & 70 & 80 \\
\hline A18 & 87 & 87 & 85 & 80 & 88 & 82 \\
\hline A19 & 93 & 91 & 80 & 85 & 80 & 91 \\
\hline A20 & 93 & 94 & 75 & 85 & 92 & 90 \\
\hline A21 & 88 & 86 & 87 & 90 & 92 & 87 \\
\hline A22 & 86 & 84 & 35 & 70 & 85 & 82 \\
\hline A23 & 82 & 82 & 40 & 75 & 70 & 82 \\
\hline A24 & 92 & 87 & 70 & 85 & 55 & 81 \\
\hline & & & & & & \\
\hline
\end{tabular}

\begin{tabular}{|l|l|l|l|l|l|l|}
\hline A25 & 82 & 84 & 55 & 70 & 90 & 65 \\
\hline A26 & 82 & 85 & 65 & 80 & 65 & 50 \\
\hline A27 & 85 & 82 & 75 & 85 & 70 & 80 \\
\hline A28 & 82 & 90 & 45 & 70 & 78 & 82 \\
\hline A29 & 84 & 89 & 65 & 80 & 55 & 75 \\
\hline A30 & 82 & 92 & 70 & 90 & 45 & 70 \\
\hline A31 & 89 & 88 & 75 & 100 & 60 & 75 \\
\hline A32 & 84 & 84 & 75 & 90 & 40 & 95 \\
\hline A33 & 85 & 85 & 80 & 90 & 60 & 58 \\
\hline A34 & 88 & 89 & 90 & 100 & 60 & 45 \\
\hline A35 & 88 & 89 & 40 & 91 & 90 & 95 \\
\hline A36 & 86 & 85 & 85 & 95 & 30 & 55 \\
\hline A37 & 83 & 84 & 95 & 80 & 90 & 75 \\
\hline A38 & 82 & 81 & 85 & 73 & 30 & 60 \\
\hline A39 & 81 & 81 & 60 & 50 & 60 & 80 \\
\hline A40 & 89 & 90 & 100 & 95 & 60 & 75 \\
\hline A41 & 83 & 82 & 75 & 53 & 50 & 45 \\
\hline A42 & 85 & 85 & 80 & 100 & 25 & 75 \\
\hline A43 & 80 & 79 & 45 & 85 & 20 & 55 \\
\hline A44 & 78 & 76 & 60 & 70 & 25 & 45 \\
\hline A45 & 83 & 81 & 60 & 65 & 35 & 68 \\
\hline A46 & 80 & 76 & 70 & 80 & 20 & 55 \\
\hline A47 & 81 & 77 & 90 & 70 & 30 & 65 \\
\hline A48 & 84 & 84 & 50 & 83 & 90 & 100 \\
\hline A49 & 80 & 77 & 90 & 90 & 40 & 75 \\
\hline A50 & 78 & 79 & 55 & 68 & 35 & 47 \\
\hline A51 & 84 & 86 & 55 & 93 & 75 & 100 \\
\hline A52 & 82 & 84 & 50 & 75 & 40 & 87 \\
\hline A53 & 82 & 80 & 70 & 70 & 30 & 76 \\
\hline A54 & 81 & 80 & 100 & 70 & 70 & 50 \\
\hline A55 & 79 & 77 & 60 & 45 & 30 & 76 \\
\hline A56 & 82 & 79 & 90 & 93 & 30 & 43 \\
\hline A57 & 82 & 83 & 95 & 95 & 45 & 70 \\
\hline A58 & 79 & 80 & 80 & 73 & 15 & 55 \\
\hline A59 & 81 & 82 & 60 & 80 & 30 & 40 \\
\hline A60 & 82 & 84 & 56 & 80 & 20 & 55 \\
\hline A61 & 79 & 81 & 75 & 40 & 75 & 65 \\
\hline A63 & 77 & 76 & 60 & 35 & 10 & 40 \\
\hline 83 & 78 & 50 & 73 & 60 & 75 \\
\hline 83 & 82 & 60 & 80 & 40 & 95 \\
\hline 85 & 84 & 80 & 100 & 60 & 45 \\
\hline
\end{tabular}
Source: (Nadya, 2014:43; Mentari, 2014:40)

The data above is nor normal and that is not fulfill the discriminant assumption. That is why the data is normalized to minimize errors made. One way to normalize data is to use natural logarithms. Data after the normalization of the student's scores on the material of space and algebra and the value of the math and science report cards are showed in the followig table.

\begin{tabular}{|l|l|l|l|l|l|l|}
\hline GROUP & X1 & X2 & X3 & X4 & X5 & X6 \\
\hline
\end{tabular}


Discriminant Analysis Through Fisher Method on Student's Materials Building in SMP 1 Banda Aceh Yuhasriati, Johan Yunus, Erni Maidiyah, Bintang Zaura

\begin{tabular}{|c|c|c|c|c|c|c|}
\hline 2 & 4,431 & 4,431 & 3,689 & 4,094 & 4,489 & 4,407 \\
\hline 1 & 4,477 & 4,477 & 4,382 & 4,443 & 3,912 & 4,407 \\
\hline 2 & 4,564 & 4,533 & 4,466 & 4,500 & 4,443 & 4,533 \\
\hline 2 & 4,564 & 4,522 & 4,522 & 4,500 & 4,318 & 4,511 \\
\hline 1 & 4,543 & 4,522 & 4,443 & 4,466 & 4,443 & 4,443 \\
\hline 2 & 4,564 & 4,533 & 4,443 & 4,500 & 4,248 & 4,522 \\
\hline 2 & 4,564 & 4,522 & 4,466 & 4,500 & 4,466 & 4,511 \\
\hline 2 & 4,511 & 4,477 & 3,555 & 4,094 & 3,912 & 4,407 \\
\hline 2 & 4,419 & 4,419 & 3,912 & 4,094 & 3,807 & 4,407 \\
\hline 1 & 4,554 & 4,543 & 4,500 & 4,554 & 4,443 & 4,522 \\
\hline 1 & 4,407 & 4,407 & 4,466 & 4,500 & 4,466 & 4,443 \\
\hline 1 & 4,564 & 4,533 & 4,500 & 4,554 & 4,443 & 4,522 \\
\hline 1 & 4,521 & 4,450 & 4,500 & 4,500 & 4,407 & 4,466 \\
\hline 1 & 4,521 & 4,477 & 4,443 & 4,500 & 4,466 & 4,500 \\
\hline 1 & 4,521 & 4,489 & 4,407 & 4,443 & 4,407 & 4,407 \\
\hline 1 & 4,466 & 4,454 & 4,443 & 4,443 & 4,500 & 4,443 \\
\hline 1 & 4,454 & 4,443 & 4,174 & 4,382 & 4,248 & 4,382 \\
\hline 2 & 4,466 & 4,466 & 4,443 & 4,382 & 4,477 & 4,407 \\
\hline 2 & 4,533 & 4,511 & 4,382 & 4,443 & 4,382 & 4,511 \\
\hline 2 & 4,533 & 4,543 & 4,318 & 4,443 & 4,522 & 4,500 \\
\hline 1 & 4,477 & 4,454 & 4,466 & 4,500 & 4,522 & 4,466 \\
\hline 2 & 4,454 & 4,431 & 3,555 & 4,248 & 4,443 & 4,407 \\
\hline 2 & 4,407 & 4,407 & 3,689 & 4,318 & 4,248 & 4,407 \\
\hline 1 & 4,522 & 4,466 & 4,248 & 4,443 & 4,007 & 4,394 \\
\hline 1 & 4,407 & 4,431 & 4,007 & 4,248 & 4,500 & 4,174 \\
\hline 1 & 4,407 & 4,44 & 4,174 & 4,382 & 4,174 & 3,912 \\
\hline 1 & 4,443 & 4,4067 & 4,318 & 4,443 & 4,248 & 4,382 \\
\hline 2 & 4,407 & 4,500 & 3,807 & 4,248 & 4,357 & 4,407 \\
\hline 1 & 4,431 & 4,489 & 4,174 & 4,382 & 4,007 & 4,318 \\
\hline 1 & 4,407 & 4,522 & 4,248 & 4,500 & 3,807 & 4,248 \\
\hline 1 & 4,489 & 4,477 & 4,318 & 4,605 & 4,094 & 4,318 \\
\hline 2 & 4,431 & 4,431 & 4,318 & 4,500 & 3,689 & 4,554 \\
\hline 1 & 4,443 & 4,443 & 4,382 & 4,500 & 4,094 & 4,060 \\
\hline 1 & 4,477 & 4,489 & 4,500 & 4,605 & 4,094 & 3,807 \\
\hline 2 & 4,477 & 4,489 & 3,689 & 4,511 & 4,500 & 4,554 \\
\hline 1 & 4,454 & 4,443 & 4,443 & 4,554 & 3,401 & 4,007 \\
\hline 1 & 4,419 & 4,431 & 4,554 & 4,382 & 4,500 & 4,318 \\
\hline 1 & 4,407 & 4,394 & 4,443 & 4,290 & 3,401 & 4,094 \\
\hline 2 & 4,394 & 4,394 & 4,094 & 3,912 & 4,094 & 4,382 \\
\hline 1 & 4,489 & 4,500 & 4,605 & 4,554 & 4,094 & 4,318 \\
\hline 1 & 4,419 & 4,407 & 4,318 & 3,971 & 3,912 & 3,807 \\
\hline 1 & 4,443 & 4,443 & 4,382 & 4,605 & 3,219 & 4,318 \\
\hline 1 & 4,382 & 4,369 & 3,807 & 4,443 & 2,996 & 4,007 \\
\hline 1 & 4,357 & 4,331 & 4,094 & 4,248 & 3,219 & 3,807 \\
\hline 2 & 4,419 & 4,394 & 4,094 & 4,174 & 3,555 & 4,219 \\
\hline
\end{tabular}

Jurnal Geuthèë: Penelitian Multidisiplin Vol. 02, No. 02, (Agustus, 2019), pp. 301-307.

\begin{tabular}{|l|l|l|l|l|l|l|}
\hline 1 & 4,382 & 4,331 & 4,248 & 4,382 & 2,996 & 4,007 \\
\hline 1 & 4,394 & 4,344 & 4,500 & 4,248 & 3,401 & 4,174 \\
\hline 2 & 4,431 & 4,431 & 3,912 & 4,419 & 4,500 & 4,605 \\
\hline 1 & 4,382 & 4,344 & 4,500 & 4,500 & 3,689 & 4,318 \\
\hline 1 & 4,357 & 4,369 & 4,007 & 4,219 & 3,555 & 3,850 \\
\hline 2 & 4,431 & 4,454 & 4,007 & 4,533 & 4,318 & 4,605 \\
\hline 2 & 4,407 & 4,431 & 3,912 & 4,318 & 3,689 & 4,466 \\
\hline 2 & 4,407 & 4,382 & 4,248 & 4,248 & 3,401 & 4,330 \\
\hline 1 & 4,394 & 4,382 & 4,605 & 4,248 & 4,248 & 3,912 \\
\hline 2 & 4,369 & 4,344 & 4,094 & 3,807 & 3,401 & 4,330 \\
\hline 1 & 4,407 & 4,369 & 4,500 & 4,533 & 3,401 & 3,761 \\
\hline 1 & 4,407 & 4,419 & 4,554 & 4,554 & 3,807 & 4,248 \\
\hline 1 & 4,369 & 4,382 & 4,382 & 4,2905 & 2,708 & 4,007 \\
\hline 1 & 4,394 & 4,407 & 4,094 & 4,382 & 3,401 & 3,689 \\
\hline 1 & 4,407 & 4,431 & 4,025 & 4,382 & 2,996 & 4,007 \\
\hline 2 & 4,369 & 4,394 & 4,318 & 3,689 & 4,318 & 4,174 \\
\hline 2 & 4,344 & 4,331 & 4,094 & 3,555 & 2,303 & 3,689 \\
\hline 2 & 4,394 & 4,357 & 3,912 & 4,290 & 4,094 & 4,318 \\
\hline 2 & 4,382 & 4,407 & 4,094 & 4,382 & 3,689 & 4,554 \\
\hline 1 & 4,419 & 4,394 & 4,318 & 4,419 & 4,094 & 4,060 \\
\hline 1 & 4,407 & 4,431 & 4,382 & 4,605 & 4,094 & 3,807 \\
\hline
\end{tabular}

Using SPSS software (version 16.0) analyzed by discriminant and the discriminant analysis results will be formed on the new sheet. The main thing that is obtained through SPSS software is the relationship between all variables. Then, obtained Fisher linear discriminant function in the following table.

Based on the classification above, so the discriminant function we have:

$$
\begin{aligned}
& Y_{\text {prism\&pyramid }}= 955,086 X_{1}+1583,05 X_{2}-28,202 X_{3} \\
&-127,773 X_{4}-120,111 X_{5} \\
&- 92,511 X_{6} \\
& Y_{\text {algebra }}=956,411 X_{1}+1589,179 X_{2}-34,065 X_{3} \\
&-137,536 X_{4}-120,797 X_{5} \\
&-82,946 X_{6}
\end{aligned}
$$




\section{Classification Function Coefficients}

\begin{tabular}{|l|c|c|}
\hline \multirow{2}{*}{} & \multicolumn{2}{|c|}{ Student Identity } \\
\cline { 2 - 3 } & $\begin{array}{c}\text { DOMINA } \\
\text { TE }\end{array}$ & $\begin{array}{c}\text { NOT } \\
\text { MASTER }\end{array}$ \\
\hline $\begin{array}{l}\text { The Value of } \\
\text { Mathematics } \\
\text { Report Card of } \\
\text { Science }\end{array}$ & 955.086 & 956.411 \\
$\begin{array}{l}\text { Pretest P\&L } \\
\text { Postest P\&L } \\
\text { Pretest Algebra }\end{array}$ & -1583.050 & 1589.179 \\
Postest Algebra & -127.20 .111 & -34.065 \\
(Constant) & -4860.884 & -137.536 \\
\hline
\end{tabular}

Fisher's linear discriminant functions

By using descriptive analysis, through software SPSS (version 16.0) obtained students who have mastered the building material about the prism and pyramid of 12 students and if in the percentage of students who have mastered the material is $18.18 \%$ and students who have not mastered the material is 54 students with the percentage of $81,82 \%$.

For example, suppose there are Z1 students with math grades 89, IPA 91 grades, pre-test prism and 50 peak, post prism and pyramid 90 preliminary, algebra pre-test value 78 , and algebraic post-test value 90 After normalized with natural logarithm becomes $\mathrm{X} \_1$ $=4,4886$; X_2 $=4,5108 ;$ X_3 = 3,912; X_4 = 4,$4998 ; \mathrm{X} \_5=4,3567$; and $\mathrm{X} \_6=4,4998$. Substituting into discriminant function will be obtained:

$$
\begin{aligned}
Y_{\text {prism and limas }}= & 955,086(4,4886)+1583,05(4,5108) \\
& -28,202(3,912)-127,773(4,4998)
\end{aligned}
$$

$$
\begin{gathered}
120,111(4,3567)- \\
92,511(4,4998) \quad \\
Y_{\text {prism\&pyramid }}=9802,9732 \\
Y_{\text {aljabar }}=956,411(4,4886)+1589,179(4,5108) \\
-34,065(3,912)-137,536(4,4998) \\
- \\
120,797(4,3567)-82,946(4,4998) \\
Y_{\text {aljabar }}=9809,7515
\end{gathered}
$$

The above results show $\mathrm{Y}_{-}$algebra $\>\mathrm{Y} \rrbracket$ _ (prism and pyramid), so that Z1 students enter into a controlling group or group that has not mastered prism and pyramid.

\section{CONCLUSION}

Referring to the results of this study obtained some conclusions, including:

Prism and pyramid material is one of the material that is difficult to be mastered by grade VIII students in SMP Kasih Banda Aceh. This is indicated by the results of research calculations through the linear discriminant function fisher with the help of software SPSS (version 16.0) where the students who master the material wake up space about prism and pyramid as many as 12 people with percentage of $18.18 \%$ and students who have not mastered the material as much as 54 people with a percentage of $81.82 \%$. This indicates that students who have not mastered the building material about prism and pyramid more than students who mastered the material.

Fisher linear discriminant functions obtained through SPSS software (version 16.0) are:

$$
\begin{aligned}
& Y_{\text {prism\&pyramid }}= 955,086 X_{1}+1583,05 X_{2}-28,202 X_{3} \\
&-127,773 X_{4}-120,111 X_{5} \\
&- 92,511 X_{6} \\
& Y_{\text {algebra }}=956,411 X_{1}+1589,179 X_{2}-34,065 X_{3} \\
&- 137,536 X_{4}-120,797 X_{5} \\
&- 82,946 X_{6}
\end{aligned}
$$




\section{REFERENCE}

Dillon.W.R \& Goldstein.M, (1984), Multivariate Analysis Method and Application. Sons, New york. Johnson, R, A., D. W. Wichern, (1988), Applied Multivariate Statistical Analysis, Prentice Hall, Inc, New jersey

Kathleen. M, \& Carmen. A, (2002), SPSS for instutional researchers, Bucknell University.

Kleinbaum, R, A, \& L.L. Kupper, (1978). Applied Multivariate Analysis and Other Multivariate Methods. Ruxbury Press, Massachusects.

Mentari, Mutia. (2014). Analisis Diskriminan Melalui Metode Fisher untuk Mengelompokkan Tingkat Penguasaan Matematika Siswa Kelas Unggul MTsN Model Banda Aceh. Banda Aceh: Universitas Syiah Kuala.

Nadya.( 2014). Analisis Diskriminan Melalui Metode Fisher Terhadap Kemampuan Siswa dalam Menguasai Materi Bangun Ruang Kelas VIII SMP Negeri 1 Banda Aceh Tahun Pelajaran 2013/2014. Banda Aceh: Universitas Syiah Kuala.

Umam, K.(2015). Analisis Diskriminan Melalui Metode Fisher Terhadap Kemampuan Siswa dalam Menguasai Materi Bangun Ruang Kelas VIII SMP Negeri 1 Banda Aceh Tahun Pelajaran 2013/2014. Jurnal Natural, 15(1): 25.

http://eprints.walisongo.ac.id/1657/4/093511013_Bab2.pdf

Rifai, A. Pengaruh Sosial Ekonomi terhadap Prestasi Belajar Siswa SD.accessed though https://www.slideshare.net/AdeRifaiKolot/makalah-pengaruh-sosial-ekonomi-terhadapprestasi-belajar-siswa-sd-di-sd 